\title{
THE CAPTURE OF HAYNES BLUFF BY THE 4TH IOWA CAVALRY
}

\author{
by Margie Riddle Bearss \\ Arlington, Virginia
}

Mrs. Bearss was born and reared in Mississippi where her interest in the Civil War began. She has made the exhibits (maps, dioramas, paintings and displays) for the Grand Gulf Military State Park in Grand Gulf, Mississippi, and has cataloged all the artifacts from the salvaged Civil War gunboat, CAIRO. She is a Fellow in the Company of Military Historians and Collectors.

In addition to the original letter of Captain John Peters in the Rigby Collection in the files of the Vicksburg National Military Park, and the logs of the gunboats, Mrs. Bearss consulted The Story of a Cavalry Regiment: The career of the Fourth Iowa Veteran Volunteers by William Forse Scott in the preparation of this article.

In May 1863, as Maj. Gen. Ulysses S. Grant attempted to capture Vicksburg, Mississippi, he battered his way inland from Bruinsburg Landing, fighting the battles of Port Gibson, Raymond and Jackson. After the decisive battle of Champion Hill on May 16, 1863, the Confederates retreated into the city of Vicksburg. General Grant surrounded the city and the siege began.

One of the important but little known events of the "closing in on the city" was the capture of Haynes Bluff. Reference to it is usually brief, and the general impression is that the Union gunboats captured this formidable complex which guarded Vicksburg's approaches from the Yazoo River. Headlines in the St. Louis papers heralded "From Vicksburg - Capture of Haynes Bluff - Gallant Participation of the River Fleet - Official Dispatch from Admiral Porter."

However, the true story of the capture is recorded in official reports and is substantiated by the logs of the gunboats. The most vivid account is told in an original letter written by 
the Captain of the 4th Iowa Cavalry, John H. Peters ${ }^{1}$ to Capt. William T. Rigby, an Iowa soldier from Cedar county. The letter, headed Manchester, Iowa, Feb. 8, 1900, in its entire original form, is as follows:

"It will be remembered that our (4th Iowa Cav.) was the only Cav. regt. that accompanied Gen. Grant's command from Grand Gulf to Jackson and from thence back to the rear of Vicksburg \& participating in most of the hard fought battles in that memorable campaign.

It was my old " $B$ "s that burned the railroad bridges between Jackson \& Brandon ${ }^{2}$ in the night after the first battle of Jackson to prevent Johnson (Gen. Joseph E. Johnston) from forming a connection with Pemberton. It was a little bit of an enterprise inconsiderable in itself yet it succeeded in flustrating the plans of that wily old chief. Again as you were there, you will remember that memorable night of the 18th of May as 1863 after the rebel schirmishers had been driven into the fortifications \& our men settled down for the night. $^{3}$ The gloomy report was circulated to the effect that our bread rations was exausted or so nearly so that the commissary could not furnish one hardtack apiece for all the men. A consultation was held at Grant's Hd Qrs. and the conclusion arrived at was that communications with our transports must be established on the Mississippi via the Yazoo or the Siege must be abandoned.

Accordingly orders were issued to the 4th Iowa to immediately proceed and make thorough reconnaisance of Haynes Bluff. (In Union reports and communications Haynes Bluff and Snyder's Bluff were almost always confused.

'John H. Peters was born Feb. 2, 1829, at Kent, Pennsylvania. He was elected Captain of Co. B 4th Iowa Cavalry, Sept. 23, 1861. He was promoted from Captain to Lieutenant Colonel on Oct. 6, 1863. He died July 19, 1927.

${ }^{2}$ Brandon was 12 miles east of Jackson on what was the Southern Railroad of Mississippi.

${ }^{3}$ After the battle of Champion Hill on May 16, 1863, the defeated Confederates retreated in disorder to the Big Black River where they fought a holding action and then fell back into the Vicksburg fortifications. 
Snyder's Bluff ${ }^{4}$ was a heavily fortified complex with trenches and 14 heavy guns. Snyder's Bluff complex was probably the most extensive and elaborate in construction of all then in the Confederacy. Haynes Bluff, about three miles north of Snyder's Bluff, was of little consequence as a fortification.)

We started just at day light but our march was greatly impeded by the frequent capture of squads of footsore and nearly exhausted reb soldiers that had escaped from Champion Hill and Blackriver bridge (Big Black River) battlefields trying to make their way through the woods into Vicksburg. Through information gained from these soldiers, the Negroes and perhaps some citizens we supposed we had practically a pretty correct knowledge of the number and location of the reb forces in that vicinity ${ }^{5}$-viz a camp on the Brownsville road containing about $4000 \mathrm{men}^{\circ}$ and in the Haynes and Snyder's bluffs fortification about 10,000 men. ${ }^{7}$ At about noon we had reached a point near the junction of the road on which we were marching and the Brownsville road. Here a consultation of officers was called, the condition of things talked over and a vote taken on the proposition as to whether we should advance or retire and with the exception of your humble servant the vote to retire was unanimous. If our information was correct after crossing the Brownsville road we would have the whole force of the two fortifications in our front and the 4000 camped only a mile or two up the Brownsville road in our rear, while as you will remember those deep narrow ditches so profusely scattered among the hills utterly prevented flank movements by cavalry so it was no wonder that our officers thought discretion the better part of valor and decided to retire. Well, our regiment was reversed by squadrons and the march toward camp began.

${ }^{4}$ Confederate fortifications at Snyder's Bluff had been commanded by Brig. Gen. Louis Hebert. Though there had been 3,000-3,500 troops there earlier, they had been withdrawn on the night of the 17th to Vicksburg.

${ }^{5}$ There were, in reality, only stragglers left.

${ }^{6}$ There was no Confederate camp on Brownsville road at this time. This was misinformation.

'There had been 2,500 men there but they had evacuated the night of May 17 and pulled back into Vicksburg. 
Riding with the Col. (Simon D. Swan) ${ }^{8}$ at the rear of the column I begged him to allow me to take my old "B"s and go back to complete our reconnaisance or at least to proceed until we had heard the sound of a hostile gun. Col. Swan finally and very reluctantly gave his consent and II rode forward to my old co. and called for volunteers to go with me into Haynes Bluffs, the whole co. to a man turned out and as we reached the rear of the column I ordered the men to move by file and stationing myself so as to get a good view of the horses not men. All the men were good but I wanted only such horses as in my judgment could carry its rider in a long and fast race should it become necessary and when my selection was completed out of the 65 or 70 men I had just 23 men and 3 officers. A lieut. from Co. A had volunteered to take his place in the ranks so my command consisted of 24 men and 3 officers. Forming then took the gallop in the direction of the Yazoo and that gate was not slackened until we reached the base and rear of Snyder's Bluff. In the meantime we had captured a mounted rebel soldier a native of the Green Isle who claimed to have been forced into the rebel ranks but with promise of his freedom and a free pass to St. Louis he agreed to pilot me into the fortifications by a by path that would avoid the reb pickets. This be done by conducting us into a bridle path that led up through the wooded side of the bluff in rear of the works. At about three fourths of the way to the summit we came out into a broad military road that wound around into and above the works. I shall never forget the sight. Before us lay the broad Yazoo and from the landing up to our very feet lay (with the exception of Vicksburg) the most complete and strongest fortification of the whole Mississippi valley. We rode forward expecting every minute a demonstration that would send us back at a livelier pace than we had come in. All at once there poured out a squad of armed soldiers from a large commissary building of the left of the road 25 or 30 in number and undertook to form a line in our front. In a moment the order came left front into line Draw sabres Charge and in a moment

${ }^{8} \mathrm{Col}$. Simeon D. Swan was mustered in as Major in the 4 th Iowa at Mt. Pleasant, Iowa, Nov. 23, 1861. 
we were down upon them. Not a gun was fired nor a serious saber stroke given. They simply threw down there arms and surrendered. From the Sergt. in command I learned that the fortifications had been evacuated the night before. A bridge had been thrown across the Chickasaw Bayou and the command moved across and under the bluffs around Sherman's right into Vicksburg with the intention of returning the following night and removing as much of their stores as possible and this small guard over their commissaries was all the armed soldiers that remained, some hundred or more convalescents and camp followers were picked up and together with our prisoners were marched down to the landing and kept under guard.

At this time I sent a man to the top of the bluff with a fairly clean towel that I happened to find in my saddle pocket to try and signal a gunboat that I could see lying a mile or two down the river. ${ }^{9}$ Soon after I rode up myself to see the effect of my effort to get the attention of gunboat. With my glass I could plainly see a squad of officers on the deck with their glasses pointed in our direction but making no effort to communicate with us. I then directed Lieut. Clark $^{10}$ to take a couple of men and follow down the river bank until he could communicate with the boat. I then selected 3 men to accompany me and started for Haynes Bluff ${ }^{11}$ comparatively an insignificant fortification about 3 miles up the river. Here not a single rebel soldier was to be found. It appeared as tho the comd. had stepped around the bluff out of sight. An old planter and a score of Negroes were repairing the old ferryboat to cross the river and after being assured that no harm was intended for them the old gentleman became communicative and informed me that the garrison had suddenly evacuated the place the night before. So after counting the

${ }^{9}$ Union fleet anchorage was at the mouth of the Yazoo. Baron De Kalb (gunboat), Choctaw (ironclad), Linden (tinclad), Romeo (tinclad), Petrel (tinclad), and Forest Rose (tinclad) had been dispatched up the Yazoo to open communications with Grant but they were lying well out of range of the guns of Snyders Bluff.

${ }^{10} \mathrm{Lt}$. Alonzo Clark was mustered in as Lieutenant in Co. B 9th Iowa on Oct. 16, 1861, at Mt. Pleasant, Iowa.

${ }^{11}$ Captain Peters did not confuse Snyder's and Haynes. 
guns $^{12}$ estimating camp and garrison equipage and comisary stores I set out on my return and reached the landing at Snyder's Bluff a little after dark and found the gunboat De Calb tied to the bank. Our prisoners all on board and my boys after partaking of the first square meal since crossing the river at Grand Gulf, were coming ashore with pockets and hats full of hardtack. My invitation to go aboard and take supper was so pushing that I was taken from the saddle and carried to the officers messroom. The prospects of a good supper after a fast of 12 or 14 hours and a ride of over 20 miles to say nothing of the intense excitement during most of the time settled the question and I became the guest of the Capt. and did ample justice to a splendid supper with all the et cetera that not provided for are not prohibited in the regulations of the commissary department of the Navy. So after signalling an orderly boat and preparing a message to our fleet of transports on the Miss. notifying them to the effect that the Yazoo was open up to Chickasaw Bayou, we climbed upon the backs of our hungry and tired horses and rode rapidly back toward the place we had left the regt. The Col. had promised to throw the regt. into line so that in case we should find it necessary to return very hastily he could give us support but on reaching the point all was silent. Pickets that had been thrown out to the front had reported heavy firing in the direction of the bluffs and after waiting for a few hours the prophecy of the many had been fulfilled as they believed. The Capt. and little squad had found a rebel prison or a soldiers grave and so they had returned and reported "Our Capt., 3 Lieut. and 23 men either killed or captured and the expedition a failure."

So after finding ourselves deserted we took a more moderate gate and reached our camp on the Marshall plantation a little after midnight to the utter surprise and great joy of our whole command.

After a short rest and a fresh mount I reached Gen. Grant's Hdgrs. a little after 2 o'clock in the morning and

${ }^{12}$ Guns at Snyder's Bluff were $14-$ all 8 and 10 inch smoothbore and $7 \frac{1}{2}$ inch rifled. 
verbally reported the capture of Snyder's and Haynes Bluffs and of the notice sent to the transports. My report was very thankfully received. Orderlies were dispatched and soon Genls. Sherman, McPherson and many others put in an appearance and my story was repeated.

Among others that helped to fill the tent was Frank Wilkey formerly on the Dubuque Herald but at the time a correspondent of the New York Sun. He kindly informed me that he had just completed the finest obituary he had ever written and for the present at least I might as well consider myself among the slain. Some ten days thereafter copies of a St. Louis paper ${ }^{13}$ was received in camp containing a lengthy report preporting to eminate from Rear Admiral Porter describing a battle between the gunboats and the Forts resulting in the capture of the fortifications and a large amount of ordnance and camp and garrison stores. ${ }^{14}$ This report so incensed Genl. Sherman that he came to our camp and enquired of me the names of the Lieuts. that accompanied me on that expedition. These officers were sent for and appeared before the Genl. who directed them to retire to their several quarters and each make a full report of that expedition. Each report to be sworn to. In about half an hour they returned their several reports sworn to before the adjutant. After questioning each of them very closely he left taking the reports with him and his report as well as Gen. Grant's confirmed my statements. Gen. Grant never forgave Rear Admiral Porter for the false report made by him or some of his officers regarding this matter for down as late as when he was President in some communication connected with the Admiral he gave the account substantially as I have given."

Sincerely yours, J. H. Peters

(Signed)

${ }^{13}$ St. Louis paper was The Missouri Democrat, May 26, 1863.

${ }^{14}$ Official records from Admiral Porter sound as though the forts were captured by the gunboats. 
Close examination of the logs of the gunboats ${ }^{15}$ reveals their activities which verify Captain Peters' story. The log of the Forest Rose shows little more than routine activity on May 19-no mention of firing on forts.

At $7: 45$ a.m. saw a flag of truce up the river and sent a tug with the Executive officer to meet it. At 8:15 Mr. Morgan returned bringing 3 rebel deserters. Capt. Brown then took them to the Baron De Kalb returning at 9:25. At 5:45 the Baron De Kalb, Choctaw, Forest, Rose and a tug got under way. At 2 came in sight of Haynes Bluff. When Capt. Breeze and Signal officer got aboard the Baron De Kalb we then turned back. After running two or three miles we got orders to return and take observations. At 3 started back down the river and met the Baron $D e K a l b$. We again turned back and follow them. ...

On May 21 at 3 a.m. passed Gunboat Romeo at same time a boat came alongside with dispatches from Gen. Grant. Arrived at 3:45 at Haynes Bluff.

They went down the Yazoo to the Ordnance boat then to the coal barges where they took on 150 bushels of coal, then by the blacksmith boat and back up river. At 11 a.m. they passed the Gunboat Romeo and at 1:45 arrived at Haynes Bluff.

At 1:45 p.m. they started upriver bringing up the rear of the fleet. The crew shifted rifle guns forward.

From 4 to 6 p.m. the log read "No interruption so far." From midnight to $4 \mathrm{a} . \mathrm{m}$. on May 22 the $\log$ read "all quiet on shore."

At 7 a.m. "the crews go ashore and roll 6 boilers, chimneys etc. into the river. At 7:30 sent a party of men ashore to stop rebels from carrying off ammunition wagons."

From 8 a.m. til noon "crew ashore destroying rebel property."

At 1:30 "put a marine in irons for disobeying orders. 2:30 put contraband in irons for stealing."

"At 6, 2 seamen Thompson and Lockwood are put in double irons for returning drunk and disorderly."

At 10 p.m. they left Haynes. Bluff after reporting "some noise was heard on shore and musket was fired."

${ }^{15}$ Logs of the Linden, Petrel and Forest Rose were examined. Baron De Kalb's log was lost when it was sunk by torpedoes at Yazoo City. 
So from the $\log$ of Forest Rose comes proof that the crew of the Forest Rose had no part in capturing Haynes and Snyders Bluff - they only went on shore after the fort was secured. The $\log$ of the Baron De Kalb went to the bottom of the Yazoo with her when she became the second victim of a torpedo.

The Petrel reported that they heard 5 cannon shots in the direction of Vicksburg on May 18. At 3:15. (p.m.) May 19, Petrel reported that H. E. Buchanan, Private, Co. A, 30 Missouri Volunteers, came across the Yazoo with dispatches from General Sherman to Admiral Porter. The Petrel took Private Buchanan to the flagship Black Hawk.

At 7:55 p.m. May 19, Petrel "arrived at Snyder's Bluff. After a patrol we arrived again at Snyder's Bluffs at 5 p.m. May 20 and landed alongside Rebel Steamboat Alonzo Childe."

At 12 noon the log states tersely "Burned a mill and lot of tents at Haines Bluffs."

The Petrel was fired on from Liverpool Bluffs but not from Haynes or Snyders.

The Linden on May 20 reported lying at Haynes Bluff below the raft which had been evacuated by the rebels. At 11:30 "The crews of the different Gunboats are still ashore destroying the guns, tents and magazines."

And so the gunboats arrived at Haynes Bluff after it was taken by the 4th Iowa Cavalry. No wonder Peters and his men were not too happy with the following inaccurate headline and story that appeared in various newspapers:

FROM VICKSBURG--CAPTURE OF HAINES BLUFF-GALLANT PARTICIPATION OF THE RIVER FLEETOFFICIAL DISPATCH FROM ADMIRAL PORTER

Flagship Blackhawk-Haines Bluff Yazoo River May 20to Hon. Gideon Welles. ... On the 18th at noon firing was heard in the rear of Vicksburg which assured me that Gen. Grant was approaching the city.

The cannonading was kept up furiously for some time when by the aid of glasses I discovered a company of our artillery taking position and driving the rebels before them. I immediately saw that Gen. Sherman's division had come on to the left of Snyder's Bluff, and that the rebels at that place had been cut off from joining the forces in the city. I dispatched 
the De Kalb Lieut. Commander Walker. The Chouteau [Choctaw], Lt. Comdr. Ramsey, the Romeo, Petrel and Forest Rose all under command of Lt. Comdr. Breese, up the Yazoo to open communication in that way with Gens. Grant and Sherman. ... In the meantime Lieut. Comdr. Walker in the De Kalb pushed on to Haines Bluff which the enemy had commenced evacuating the day before, and a party remained behind in the hope of destroying or taking away a large amount of ammunition on hand.

When they saw the gunboats they came out and left everything in good order. Their guns fell into our hands.

The works at Haines Bluff are very formidable. There are 14 of the heaviest kind of mounted 8 \& 10 inch and $7 \frac{1 / 2}{2}$ inch rifled cannon, with ammunition enough to last a long siege. As the gun carriages might again fall into the hands of the enemy, I had them burned, blew up the magazine and destroyed the works generally.

I also burnt up the encampments which were permanently and remarkably well constructed looking as if the rebels intended to stay for some time. The works and encampments covered many acres of ground and the fortifications and rifle pits proper of Haines Bluff extended about a mile and a quarter. Such a network of defenses I never saw. The rebels were a year in constructing them and all were rendered useless in an hour.

So it was that a single news release incorrectly gave credit to the gunboats for the capture of Haynes Bluff. It was the 4th Iowa Cavalry that deserved the recognition.

\title{
THE ANTISLAVERY MOVEMENT IN IOWA
}

\author{
by James Connor \\ Des Moines, lowa
}

Mr. Connor is a graduate student at Drake University. The following is the first portion of a two-part article which examines the evolution of Iowa's attitudes on the great moral controversy of slavery. It is an edited version of $\mathrm{Mr}$. Connor's master's thesis in American History.

Part II of "The Antislavery Movement In lowa" will appear in the fall issue of the Annals. Sources will be given at that time. 
Copyright of Annals of Iowa is the property of State of Iowa, by \& through the State Historical Society of Iowa and its content may not be copied or emailed to multiple sites or posted to a listserv without the copyright holder's express written permission. However, users may print, download, or email articles for individual use. 